This item was submitted to Loughborough's Research Repository by the author.

Items in Figshare are protected by copyright, with all rights reserved, unless otherwise indicated.

\title{
Knowledge nodes and international networks of connection: representations of private philanthropy by elite higher education institutions
}

PLEASE CITE THE PUBLISHED VERSION

http://dx.doi.org/10.1080/14649365.2013.862845

\section{PUBLISHER}

(C) Taylor \& Francis (Routledge)

\section{VERSION}

AM (Accepted Manuscript)

\section{LICENCE}

CC BY-NC-ND 4.0

\section{REPOSITORY RECORD}

Warren, Adam P., and Morag Bell. 2019. "Knowledge Nodes and International Networks of Connection: Representations of Private Philanthropy by Elite Higher Education Institutions". figshare. https://hdl.handle.net/2134/13697. 
This item was submitted to Loughborough's Institutional Repository (https://dspace.lboro.ac.uk/) by the author and is made available under the following Creative Commons Licence conditions.

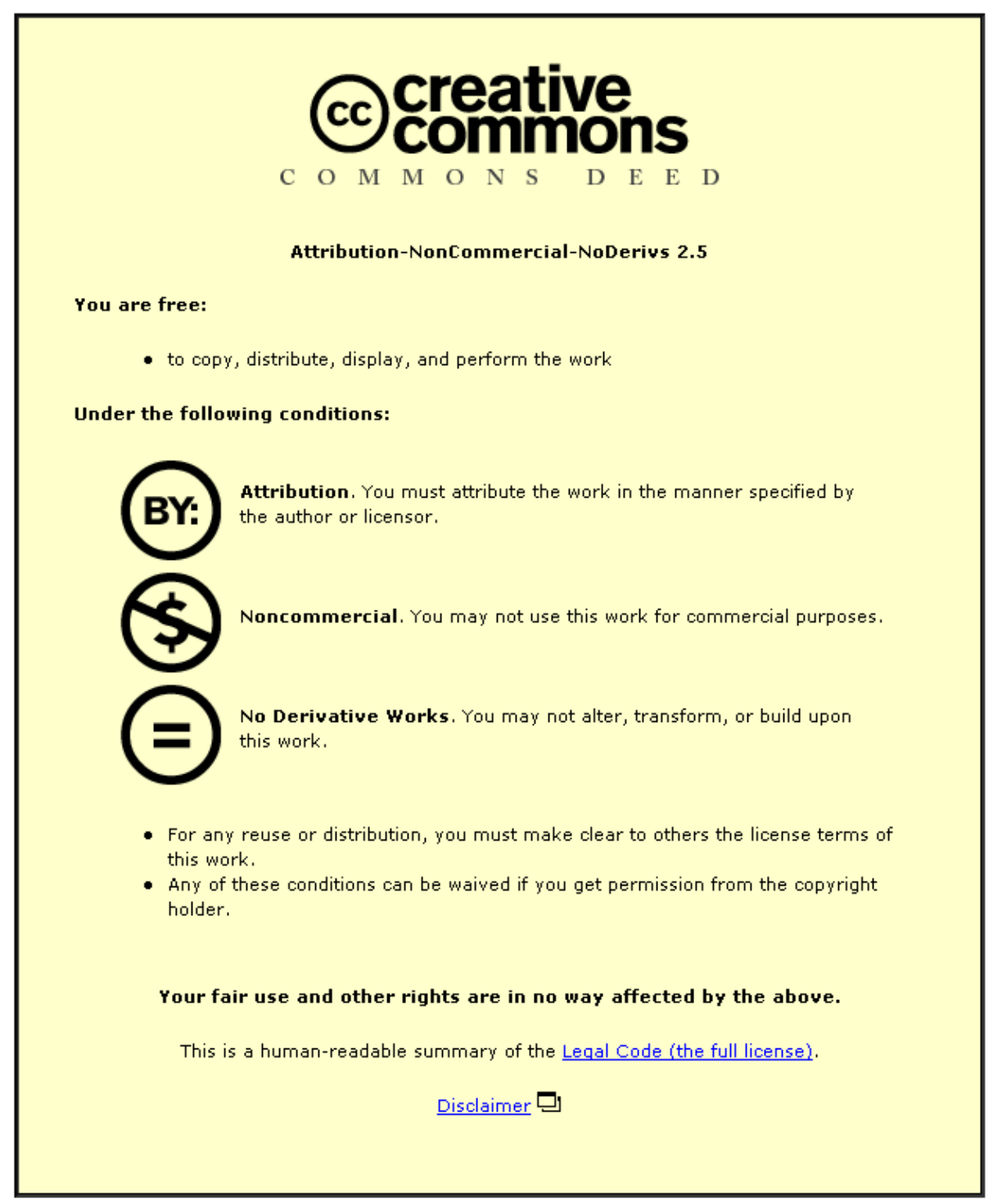

For the full text of this licence, please go to: http://creativecommons.org/licenses/by-nc-nd/2.5/ 


\title{
Knowledge Nodes and International Networks of Connection:
}

\section{Representations of private philanthropy by elite Higher Education Institutions}

\author{
Dr Adam Warren, Professor Morag Bell \\ Centre for Research in Identity, Community, Society, \\ Department of Geography, Loughborough University, Leicestershire, LE11 3TU, \\ a.p.warren@lboro.ac.uk
}

\begin{abstract}
This paper investigates the social and cultural geographies of large-scale individual giving in supporting the work of 'elite' international universities. With public funding of Higher Education in general decline, universities in countries of the global North are increasingly seeking funding from alternative sources, including private philanthropy. Although scholarly work has examined corporate and foundational giving to Higher Education Institutions (HEIs), there has been little enquiry into how donations from wealthy individuals are represented by universities in their official literature. Publications, such as Annual Reports, Giving Reports and Campaign Reports, are used strategically by HEls to project a global image. We examine the official literature of 50 elite HEls located across the globe, uncovering new discourses into the cross-cultural reach of universities. We draw attention to complex social and cultural relations between HEls and philanthropists, describing their encounters with reference to debates on personal mobilities, world-making and global and social inequalities. We conclude by highlighting the implications for theoretical work on 'strategic philanthropy' and on the transformative nature of HEls as global centres of knowledge.
\end{abstract}

Keywords: university, philanthropy, knowledge, cross-cultural, world-making, representation 


\section{Knowledge Nodes and Networks of Connection:}

\section{Representations of private philanthropy by elite Higher Education Institutions}

\section{Introduction}

An expanding body of research has examined corporate and foundational giving to universities in the UK and abroad (Ball, 2008; Schuyt, 2010; Ball and Junemann, 2011; Breeze et al, 2011). There has been less investigation into how donations from individuals are projected by institutions, or of their linkage to the mobile biographies of the philanthropists. With public funding of higher education in general decline across the countries of the global North, universities (or Higher Education Institutions (HEIs)) are increasingly seeking support from alternative sources to finance their spending on capital (including buildings and equipment), research, undergraduate and postgraduate teaching and outreach activities. Association with large-scale donors can lend prestige to an institution, increasing its appeal to potential students, academics and business partners. Moreover, if donors have overseas connections, HEls may benefit by taking the opportunity to extend their global reach and gain access to new international markets. Whilst the importance of space, place, site and territoriality have been investigated in relation to the study of scientific enterprise and the development of 'spaces of knowledge' (Livingstone, 1995: 5; see also, Driver, 1992; Livingstone, 1994, 2000; Card et al., 2010; Gluckler and Ries, 2012), there has been little analysis of how HEls use philanthropy to project a global image and, equally, how priorities for funding are shaped by the personal biographies of individual donors.

Our analysis commences with an investigation of existing literatures, in which HEls are variously conceptualised as nodes of knowledge, centres of calculation and partners in clusters of innovation. We argue that this work raises questions about representation and identity, in relation to universities and their encounters with individual donors. Specifically, we contend that 
little consideration has been given to the ways in which individual philanthropy is conceptualised and promoted in 'official' documentation produced by universities. By way of corrective, our enquiry is supported by empirical research analysing corporate documents such as Annual Reports, Giving Reports and Campaign Reports. Through an identification of the images projected by elite HEls when describing their encounters with individual donors, our analysis advances debates in social and cultural geography on personal mobilities, world-making and the perpetuation of global and social inequalities.

\section{Transformative Geographies of Institutions of Learning}

Universities have been considered historically as nodes of knowledge, exercising cultural reach beyond their locality. Livingstone, for example, investigated the ways in which the characteristics of learned societies and research laboratories in the nineteenth century were shaped by their location in particular UK cities and regions (1995: 5). This 'geography of scientific knowledge' (Livingstone, 1995: 16) has been developed in the university setting through an emerging and expanding literature interrogating the importance of place in shaping the historical geographies of 'science' (Naylor, 2005; Powell, 2007; Jöns et al, 2011), with scholars variously investigating the extent to which institutions developed specialisms in disciplines such as geography (Withers and Mayhew, 2002), life sciences (Finnegan, 2008) and psychiatry (Philo and Pickstone, 2009). In addition, the cross-cultural reach of leading HEls has been examined through studies into academic and student mobility (Ackers, 2005; Jöns, 2008, 2009, 2011; Leung, 2011; Waters et al., 2011). Specifically, Jöns has undertaken longitudinal research into academic mobility, or 'brain circulation', demonstrating its immense contribution to the development of modern research universities and, in particular, their ability to mobilise international expertise, contacts and resources across disciplines (2008, 2009, 2011). These movements have also been investigated by Hall, with reference to the ways in which business schools and management consultants seek each other out and disseminate new theories aimed 
at shaping economic practice through a 'cultural circuit of capital' (2008; see also Thrift, 2002). In addition, the implications of the transnational movements of students from Hong Kong to study in Canada has been explored by Waters, uncovering the 'cultural capital' accumulated through a 'Western' university degree (2006: 179).

Equally, academics have considered postcolonial approaches to the production and dissemination of scientific knowledge across the global North and South (Bell et al, 1995; Driver, 1992, 2001). This work has prompted a re-examination of more homogenous 'colonial' discourses on the relationship between science and empire, in which the conduct of scientific enquiry was designed to control colonial states 'at a distance' (Livingstone, 1995: 25; see also: MacLeod, 1993; Blunt, 1994; Heffernan, 1994; Shapin, 1998; Drayton, 2000; Driver, 2001; Harrison, 2005). For example, Latour (1987) argued that laboratories, museums, census bureaux - and other scientific, cultural and state institutions - acted as 'centres of calculation', generating and exchanging knowledge about other people and places to make them 'familiar and thereby controllable' (Jöns, 2009: 317). Nevertheless, this production and dissemination of learning by educational and cultural institutions was often heterogeneous and highly contested, with some scholars arguing that relations of power between the global North and South were more subtle and dynamic than 'colonialist' explanations suggested (Bell, 2002; McFarlane, 2006). More recently, Jazeel and McFarlane have used a postcolonial lens to explore the relations between 'disparate cultures of knowledge production' highlighting the ethics, politics and limitations of conducting academic research across the North-South divide, and arguing for a 'more considered engagement with the concepts of responsibility and learning' whilst avoiding the reduction of people, places or communities to 'mere "case studies" in pursuit of a (de)contextualised theoretical project' (2007: 781, 783; 2010). Within the social and cultural geographies of education, this notion of 'responsibility' across the global North and South has been specifically deployed to investigate the transformative experiences of 'international' 
students in their host country (Madge et al., 2009) and to unpack the 'embodied' writing practices of a postcolonial scholar based in a university in the global North (Noxolo, 2009).

A further corpus of literature has considered the future competitiveness of HEls, notably, their representation as 'gatekeepers', engaged with preferred partners in public and private spheres, and utilising their specialist knowledge to secure social, cultural and economic advantage across local, regional and international scales (Demeritt, 2000; Engel and del-Palacio, 2009; Hennemann, 2010; Petruzzelli et al., 2010). Benneworth and Hospers (2007), in their study of old industrial regions, argued that universities act as 'global-local pipelines', providing points of stability through which declining regions could innovate and attract external investment in knowledge capital. Engel and del-Palacio (2009), in an analysis of the role of leading research universities as partners in Clusters of Innovation $(\mathrm{COIs})^{1}$, reported that the role of HEIs within these clusters was fundamental, both in training entrepreneurs and through development of existing collaborations with industry, permitting the expansion of the COIs via global networks. Membership of networks therefore facilitated positive knowledge mobility, although Hennemann has observed that, within the international $\mathrm{HE}$ sector, there remained a tendency for elite universities to circulate global knowledge among themselves, granting 'less distinguished' universities limited (albeit improving) access (2010: 155). HEls have nevertheless sought to counter this perception of elitism, and maintain their competitive edge, through provision of often privately-funded studentships aimed at improving access (Ball, et al., 2002; Brooks and Waters, 2009; Gidley et al., 2010).

Cutting across these three literatures are various discourses on the role of philanthropic support in HEI development. Historically, philanthropy has been an important means by which universities have secured the resources to engage in, and then sustain, their transformative work as part of networks of knowledge. Granted, considerable research has been conducted on philanthropy (Owen, 1964; Odendahl, 1990; Schervish, 1994, 2005, 2006; Ostrower, 1995; 
Adam, 2004, 2009; Havens and Schervish, 2005, 2007; Kelly, 2009; Drezner, 2011). Studies have variously investigated: genealogies of philanthropy and their impact on global North-South relations, particularly in relation to the work of the Carnegie Corporation (Bell, 1998, 2000, 2002; Lambert and Lester, 2004); historical linkages between philanthropy, patronage and civil society in Germany, UK and US (Adam, 2004); philanthropy and the funding of HE in North America (Kelly, 2009; Drezner, 2011); and the promotion of academic mobility through large-scale giving (Kohler, 1985; Jöns, 2008; Collins, 2009).

Yet, there is little theoretical literature on the extent to which giving to the HE sector has been shaped by the personal geographies of wealthy donors. In her analysis of motivations for largescale giving, Odendahl (1990) contended that the preponderance of donations by the wealthiest donors tended to be directed at institutions they personally patronised, such as museums, universities and concert halls. In an investigation of elite philanthropy, Ostrower drew a distinction between giving to 'cultural institutions' (for example, the museum) - often interpreted for the donor as a 'vehicle for participating in the social life and identity of their class' (1995: 99) - and donations supporting 'educational' organisations (such as universities). She argued that the latter were frequently viewed by wealthy philanthropists as facilitating 'their material ability to participate in the elite' and, accordingly, donors supported educational institutions through a 'sense of dependency' (1995: 99). Motivations for philanthropic activity have been further ascribed to attachment to religion (Cascione, 2003), an affirmation of shared national culture (McDonald and Scaife, 2011), a response to clearly defined public needs (Pharoah, 2011) and the desire to exert greater influence, or 'world-making' (Harvey et al., 2011). In his studies of the sociology of major giving, Schervish argued that large-scale philanthropy had been inspired by the complex 'moral biographies' of the wealthy (1994: 167ff; 1998; 2006). Major donors 'define[d] a virtuous identity in relation to money', according to Schervish (1994: 168, 169), with each stage of their personal development being equated to an accompanying phase of economic 
insight. Philanthropic wealth was, therefore, 'a resource for transition' (Schervish, 1994: 202), deployed via a concept of 'hyperagency' which involved:

'the additional capacity [of the wealthy] to create an institutional and organizational environment in the world - be it at work, at home, in politics, or in philanthropy compatible to their will' (Schervish, 1994: 202).

In this paper, we investigate the ways in which leading HEls are harnessing this wealth to reinforce, and enhance, their own elite status, as projected in their official documentation. In the process, we explore how HEls are writing donor motivations into their own outward-facing narratives. Whilst the use of philanthropy by individuals and corporations to further their business objectives has been discussed elsewhere (Saiia et al., 2003; Ball, 2008; Osei-Kofi, 2010; Parry et al., 2013), there has been little research into the ways in which the concept of 'strategic philanthropy' has been applied to, and by, universities. We cannot determine the original inspiration(s) for individual philanthropic giving from researching these sources alone. Nevertheless, an analysis of HEI publications can indicate the extent to which donor motivations are used by elite institutions as a signifier of their cross-cultural reputation and 'reach'. In this sense, they can elucidate how philanthropic giving is used strategically by HEls. Granted, university publications have been examined in studies on the efficiency of selected HEIs (Abbott and Doucouliagos, 2003), the growth of university-business research partnerships (Elliott, 2006) and HEl discourses on the 'student experience' (Sabri, 2011). However, the presentation of individual philanthropic giving by international HEIs in these documents has not been subjected to critical scrutiny. This is surprising, given both the proliferation of printed and electronic resources produced by many international universities describing gift activity, and the pressures on many HEls to seek funding from 'alternative' sources to offset a relative and sustained decline in receipt of public grants. This paper opens up the debate by examining the ways in 
which the patterns, and projections, of philanthropy by elite institutions contribute strategically to how HEls seek to position themselves across the global North and South.

\section{Methods}

Our empirical work focused on a sample of 50 of the top 100 universities as ranked by Times Higher Education (THE) Thomson Reuters World University Rankings 2011-2012, published on 6 October 2011 (refer to Table 1, below). We chose this approach in order to investigate how a sample of HEls presented themselves as international institutions and to explore the projected contribution of individual philanthropists to university research agendas. THE has been publishing world university rankings since 2004, initially with education company QS and then, from 2010 (using a new methodology), with the publisher Thomson Reuters. THE Thomson Reuters World University Rankings are - along with ARWU and QS - amongst the most influential such classifications. The revised methodology devised in 2010 was praised by the president of Universities UK for using 'more robust citation methods' (Smith, 2010) and by UK Minister of State for Universities and Science for according greater weight to 'quality in teaching and learning' (Willetts, 2010). Second, the sample of 50 HEls was selected in proportion to the number of HEls a country had in the top 100. For example, 51 universities in the top 100 were located in the US, therefore 25 out of the 50 selected institutions were based in this country. Third, care was taken to ensure the geographical spread of HEls was even, with universities based in mainland Europe, Australia and Asia included in the sample. Fourth, we sought to include a mix of 'traditional' (such as Harvard and Oxford) and 'newer', often more technically focused, institutions (for example, National University of Singapore ${ }^{2}$, POSTECH ${ }^{3}$ ). Fifth, we endeavoured to include both 'public' and 'private' HEls, although we appreciated that definitions of these terms were often opaque and differed between jurisdictions. Finally, where possible, we selected HEls publishing a corporate document (for example, annual report, giving report) or displaying information about significant donations on their websites. 
***Insert Table 1 here ${ }^{\star \star *}$

A content analysis was conducted of available public documentation published by the 50 HEls to identify examples of individual philanthropic giving. Content analysis was selected as it enabled 'particular meanings expressed by an object such as a book or the body [to] be discerned according to a pattern of signifiers (that is, words, images, or practices) deemed to be present' (Dixon, 2010). By identifying commonalities and differences, this technique allowed the written content of different texts to be recorded and evaluated. In addition, it permitted the examination of human interactions, enabling a greater understanding of how selected documentation can be produced under certain conditions (Neuendorf, 2002). In this paper, the data sources were analysed with reference to the debates and gaps identified in the literature review. Specifically, we grouped the signifiers present in the selected publications under the three conceptual headings used above to describe the transformative role of HEIs, namely as: nodes of knowledge; participants in postcolonial dialogue; and sustaining future competitiveness. By detailed reference to the documentation produced by the HEls, we were able to uncover a number of prominent themes.

The use of corporate publications as a source of empirical data presented challenges of selection and interpretation, with the choice of examples being shaped by the availability of material in the public domain. In the analysis, attention was given to the intended audience for the documentation and the ways in which donations were represented by the HEI. As the start and finish dates of academic years varied across the jurisdictions where the sample HEIs were located, and as lag times for publication of hard copy documents, in particular, were similarly wide-ranging, our sample comprises material published between 1 January 2010 and 31 August 
2012 , with the latter date being the end of the final month of the academic year for many of the selected HEIs. Within this time period, we analysed documents that were published on a regular basis, for example, annual reports or equivalent, giving reports, endowment reports. Where reports appeared to be unavailable, or information on specific donations was missing, the HEI in question was contacted for further information. In almost all instances, we received a positive and helpful response from the institution. In total, over 250 such publications were examined. Other material analysed included announcements on official communications on HEI websites and via Web 2.0 technologies, such as blogs and RSS feeds.

\section{Findings}

The HEls in our sample used their official literature to highlight the 'transformative' nature of their work. Although this was not unexpected, private philanthropy was presented in ways that reinforced this change-inducing narrative. Our initial survey of elite HEI texts identified 18 themes relating to this transformative role of universities, including: custodians of heritage; facilitators of cultural exchange; leaders in public affairs; respondents to global emergencies; providers of global expertise; competitors on the world stage; enablers of social mobility; and initiators of opportunity across generations (refer to Table 2, below). Through further analysis of document content, we combined overlapping themes, and identified three metaphorical forms assumed by elite universities when describing their encounters with individual donors, namely: as centres of heritage and source of cultural dialogue; as respondents to global concerns; and as facilitators of equality of access. These metaphorical forms provided areas for further investigation.

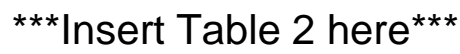




\section{(i) A centre of heritage and source of cultural dialogue}

Official documentation often referred to the institution's broader cultural heritage, drawing attention to specific spaces of learning such as the laboratory and the library (Dartmouth College, Campaign Report 2012), to particular collections, for example manuscripts or art (University of Rochester, Annual Report 2009-2010), and to the aspirations of their founders (University of Cambridge, The Philanthropist, 2012). The concept of heritage was therefore deployed in official narratives with a view to attracting potential students, academics and collaborators, including philanthropists (Moogan et al., 1999; Ball et al., 2002; Andersson et al., 2012). Visual representations in these publications reinforced the supposedly appealing nature of institutional heritage, with images of Gothic Revival architecture (University of Pittsburgh, Report of the Chancellor, 2010) and quadrangles (The University of Edinburgh, Annual Review 2010/2011) juxtaposed with state of the art laboratories (Caltech, Annual Report 2010). The following two extracts - from a German and a US university - highlighted the power of culturallysituated places in attracting direct philanthropic support:

Curt and Heidemarie Engelhorn, whose bond with Heidelberg University has developed over years of commitment to the Heidelberg Center for American Studies, have again granted the university a donation valued in the millions. The couple's gift of 4.3 million Euros is earmarked for the remodelling of the Great Hall in the New University building complex, which is being renovated in honour of the 625th anniversary of Ruperto Carola. (Universität Heidelberg, News, 16 June 2010)

John Berry has made a gift to Dartmouth of $\$ 25$ million, the core of a $\$ 30$ million gift, the largest in the College's 223-year history. With it, Dartmouth will build a companion to Baker Library - which itself will undergo expansion and renovation. More than 60 years after Baker Library confirmed Dartmouth's position in the upper echelon of education in America, 
the College approaches the 21st century with another dream about to be realized (Dartmouth College, Campaign Report 2012, 3 May 2012)

These texts are typical of many in the sample, in that the names of the donors, and the amount contributed, are mentioned in the opening sentences of the article. According to Fairclough, these 'orders of discourse' were a product of the "overdetermination' of language' by 'other social elements' (2003: 25), in effect, the interactive processes of 'meaning-making' involved in, for example, 'the production of the text, the text itself and the reception of the text' (2003: 10). The actors participating in these processes included writers, administrators and publishers in the production of the article, and readers and listeners in the reception of the article (Fairclough, 2003: 10). Thus, in many of the extracts, the order of discourse indicated that the producer (the university) believed the value of the donation and the names of the donors to be significant and of interest to the recipients (for example, alumni).

In addition, the first extract, from Heidelberg, mentioned the donor and spouse, a convention that is followed in many of the subsequent sample texts. This practice arguably has the effect of distancing the reader from the source of an individual's wealth - originating in this instance from Curt Engelhorn's career in the pharmaceuticals industry (Forbes, 2013) - and instead drew attention to the cultural value of the donation and to the donors' longer term 'commitment' to the institution, which had included earlier gifts to the Heidelberg Center for American Studies. Support of the latter also hinted at the donor's personal geographies, understood in this context to be places to which individuals were connected (Jayne et al., 2010; Valentine and Hughes, 2011). In this instance, Curt Engelhorn's mother originated from the US and Engelhorn himself had lived and studied in that country during the post-war period (Universität Heidelberg, 2013).

Moreover, we found that individual biography was presented by HEls as influencing a philanthropist's choice of recipient institution.. Accordingly, decisions on the part of the donor 
were depicted in the official HEI literature as personal acts of commemoration. For example, a UCLA online news report detailed a gift by an Iranian American husband and wife to support a Centre for Israel Studies:

The event, which was attended by Jacob Dayan, Israel's consul general in Los Angeles, and Sherry Lansing, vice chair of the UC Board of Regents, honored the Iranian American couple whose foundation has donated a total of $\$ 5$ million to create the new center. [...] The Nazarians, who are Jewish, and their four children, fled the violence and demonstrations that led up to the Iranian Revolution of 1979 , fearful that the oppressive regime would target the family for their ties to Israel. (UCLA, News, 7 October 2010)

This donation appeared to be inspired by a sense of a personal journey by the philanthropist. These 'philanthropic autobiographies' described life experiences often based around family, church, school, mentors and 'even life-shaping experiences' (Payton and Moody, 2008: 21; see also Schervish, 1994, 2006; Breeze, 2010). Equally, there was evidence that these autobiographies were connected to the homelands of previous generations. For example, in the case of the University of Toronto:

[...] a \$2-million gift from the late John Yaremko, an alumnus, has supplemented this original endowment and enabled further support of research and teaching in the history, culture and politics of Ukraine [...] (University of Toronto, Endowment Report 2011, 2011)

Similarly, in the case of New York University:

Boris (WSUC '88) and Elizabeth Jordan have donated \$5 million to establish the Jordan Family Center for the Advanced Study of Russia. The center will focus on the research, 
study, and promotion of the history, culture, politics, and economy of modern Russia. (New York University, NYU Alumni Magazine, Spring 2011)

In the above texts, the philanthropists, although born and raised respectively in Canada and the US, wished to commemorate and promote their heritage, variously associated with the history, culture and politics of the Ukraine and Russia (Livingstone, 1995; McFarlane, 2006). In October 2010, the Harvard Gazette captured a similar kind of interaction. A \$10M donation was reported by an Indian alumnus, Anand Mahindra, to enhance the well-established Harvard Humanities Center and to develop it in new ways:

It is the largest gift for the study of humanities in Harvard's history, and will advance the unique interdisciplinary collaborations led by center director Homi Bhabha. In recognition, the center will be renamed the Mahindra Humanities Center at Harvard. [...] "I am happy to be able to contribute to the cause of the humanities," said Mahindra. "To address complex problems in an interdependent world, it is vital to encourage the cross-cultural and interdisciplinary exchange of ideas in an international setting. I am proud to be part of the intellectual legacy of India's contribution to global thinking across the arts, culture, science, and philosophy. I am convinced of the need for incorporating social and humanistic concerns into the core values that inform the world of business and have sought to do so with tremendous support from my peers and colleagues at work and beyond." (Harvard University, Harvard Gazette, 4 October 2010)

This statement, with explicit reference to 'cross-cultural and interdisciplinary exchange of ideas', epitomised the notion that an individual from a country in the global South should utilise the prestige and expertise located at an elite institution situated in the global North to promote global discourses and, arguably, reshape the priorities of one of its major research centres. Although, the Humanities Center had previously engaged in collaborative work, its renaming, in 
the words of its Director, 'signals the global reach of the humanities' (Harvard University, Harvard Gazette, 4 October 2010). Through the framework of 'an interdependent world', and with a practical emphasis on 'inform[ing] the world of business', this specific act of philanthropy appeared attuned to the heterogeneity of knowledge production and exchange (Bell, 2002; McFarlane, 2006). As a result of a process of negotiation with philanthropists, HEls were thus able to broaden their cross-cultural reach in ways that challenged the elitist, and indeed colonialist, image of universities as 'centres of calculation', given to circulating knowledge primarily amongst themselves (Latour, 1987; Jöns, 2009).

\section{(ii) Responding to global concerns}

Philanthropy was used by Northern HEls to reinforce their position as global centres of learning and teaching, collaborating across countries, particularly those located in the global South (Altbach and Knight, 2007; Sidhu, 2009). Within this context, their privately funded activities were frequently development-focused (McFarlane, 2006; Glassman, 2010; Sheppard and Leitner, 2010), seeking to solve problems 'over there' (Bell, 2000; see also, Oldfield et al., 2004; Lunn, 2009; Palmer, 2010). Although it is important to be mindful of the size of these donations in relation to both the total assets of the university and the scale of the 'problems' they purported to 'solve', their genealogy can be traced back to the work of the large Northern philanthropic foundations, such as the Carnegie Corporation and the Rockefeller Foundation (Bell, 2000, 2002; Lambert and Lester, 2004). For example, Dartmouth College reported:

Dorothy and Robert King '57 have partnered with Dartmouth to help address the problem of global poverty by establishing a scholarship program for exceptional students from developing nations. They have made a gift of $\$ 14.7$ million that will fund a total of 12 King Scholars each year. The scholars will be encouraged to use their Dartmouth educations to return to their home countries after graduation to work toward the alleviation of extreme poverty. The gift also establishes an admissions recruitment fund to identify and bring 
eligible students to Dartmouth from developing countries in Africa, Latin America, and Southeast Asia. (Dartmouth College, Dartmouth Now, 29 February 2012)

This description of an act of 'benevolence' towards the global South, with its emphasis on recruiting students from 'over there' who would then return to solve 'problems' in their home countries, provides echoes of former colonialist discourses, whereby knowledge gained in the metropolitan core was used to exert control over colonial territories (Livingstone, 1995; Latour, 1987; Jöns, 2008). Yet, significantly, our analysis uncovered examples where philanthropists, from the global South, offered direct financial support to universities located in the North. The distribution of causes supported by philanthropic gifts to HEIs can discerned by reference to Table 3, below.

***Insert Table 3 here ${ }^{\star \star *}$

For example, in December 2010, the London School of Economics (LSE) reported a donation from an alumnus and his wife, both originally from Uganda:

A husband and wife, who were forced with their families to leave the brutal dictatorship of 1970s Uganda, are making a generous donation to help a new generation of African leaders develop their skills. US-based Firoz and Najma Lalji have made an initial gift of almost $£ 1$ million through their charitable foundation to help establish the Firoz and Najma Lalji Programme in African Leadership at the London School of Economics and Political Science (LSE). Each year the programme will enable 30 high-achievers from Africa to attend an intensive executive training course in London. They will benefit from high quality 
teaching in areas including government, economics, development and law from LSE and partner universities around the world. (LSE, News, 13 December 2010)

Moreover, the University of Oxford broadcast details of a gift from a Chinese businessman:

Sir Ka-shing Li is to donate $£ 5$ million to the University of Oxford to extend and strengthen the University's global health research networks with Asia, and, in particular, China. The donation from the Li Ka Shing Foundation will fund a series of partnerships, teaching and research projects that will see Shantou University in Guangdong, China become a full partner in Oxford University's Asia Research Network along with centres in Vietnam and Thailand. (University of Oxford, News, 13 May 2010)

The above gifts, from donors with roots in Uganda and China respectively, supported wideranging initiatives on the subjects of governance and public health which would benefit their country of origin. Granted, the donation to the LSE was described in paternalistic terms, with the emphasis on the 'benefit' provided to students from that institution's expertise arguably reinforcing the dominant position of elite Northern HEIs (Latour, 1987; Lambert and Lester, 2004). Nevertheless, it was an expertise provided via an infrastructure established by the overseas donors. The Ka-shing Li donation to the University of Oxford was presented as supporting a more collaborative programme, enabling the institution to work in partnership with an emerging Chinese university on various teaching and research initiatives, and, importantly, permitting the circulation of global knowledge beyond networks of elite HEls (Hennemann, 2010).

These donations were typical of the many gifts uncovered in our investigation which targeted specific, yet also timely and globally significant, topics. The HEIs in our sample highlighted gifts which resonated with contemporary concerns, for example: sustainability (Duke University, 
University of Cambridge); biodiversity (University of Oxford); food security (McGill University); and demographic change in the global South (McMaster University) (refer to Table 3, above). The selection of these nominated causes - and many others - were frequently informed by the previous experiences of the donors (Rabbitts, 2012), in their varied roles as student, researcher and / or entrepreneur. The donations may be interpreted as a desire by the philanthropist, as described in Harvey et al's research on 'world-making' entrepreneurs (2011: 425-6), to be associated with - or enhance existing connections through - elite institutions. Moreover, largescale giving was deployed to support causes that cut across the global North and South in complex ways (Latour, 1987; Jöns, 2009).

As seen with the Ka-shing Li donation, research into public health, a topic which has received significant funding from well-established foundations such as Rockefeller, Mellon and W.K. Kellogg (Oleksiyenko and Sá, 2010; LeRoy, 1999), continued to attract support from private philanthropists. Moreover, a considerable amount of large-scale philanthropic giving was aimed at addressing non-communicable diseases of the global North. For example, philanthropists supported research designed to improve outcomes for those suffering from multiple sclerosis (Uppsala University, News, 27 April 2012), diabetes (University of California, San Diego, News, 3 March 2011) and motor neurone disease (The University of Edinburgh, Annual Report 20092010). Equally, it was noticeable that private philanthropy was being used by donors, especially those based in China and South East Asia, to fund investigations undertaken by universities in the UK and North America (such as the University of Oxford, above, and McMaster University, below) into health-related conditions that were beginning to affect populations across the globe. In addition, our investigation highlighted that the research agendas of the elite universities were being influenced, and consolidated, by donations from individuals with roots in these rapidly growing states. For example, at Oxford University, a £10m donation from Hong Kong-based philanthropist Dickson Poon to the Oxford China Centre provided it with a significant physical location for the first time. In announcing receipt of the gift, the Centre's Director, Andrew Goudie, 
highlighted the opportunity it presented to engage in new partnerships and to further the exchange of ideas:

"The approach is reflective but challenging. It will not just be a Department of Sinology past, present and future, but asking critical questions about contentious issues: How sustainable can China's growth be when it consumes two billion tonnes of coal a year, faces chronic overcrowding in its cities and looming water shortages? These are global health issues and we want to look at the epidemiology on a global scale. It's not just science, but the sociology and politics, and bringing all the disciplines together." (University of Oxford, A Report on the Campaign for the University of Oxford 2010-2011)

This activity was not merely indicative of a 'reconfiguring' of the global South as a region marked by 'complex ruptures' due to varied economic growth of states (Glassman, 2010: 709, 710), it represented a shifting global dynamic, whereby experts located in the global North were addressing 'problems' of parts of the global South, defined by, and negotiated with, donors from the same region. The entangled nature of this North-South engagement was borne out in the following initiative announced by Canada's McMaster University:

A first-of-its-kind \$1-million gift from an anonymous member of McMaster's Hong Kong alumni community will fund the University's new Chair in Aging and Chinese Culture in the Faculty of Social Sciences. [...] The gift will support an expert who, during a period of seven years, will research and teach the cultural aspects of aging and the role of the elderly in China. It is the first time an alumni member from China has designated a gift of this size. "We're building a very strong network of alumni in China and Hong Kong who are enthusiastic supporters of the University," said President Peter George, who spent 12 days in China meeting with University alumni and finalizing the gift. (McMaster University, McMaster Times, Winter 2010) 
Whilst the purpose of this gift was wide-ranging, it was significant that a key priority was 'aging', a demographic characteristic once associated primarily with 'wealthy regions' of the globe. In addition, this example, of a university President celebrating the building of 'a very strong network of alumni in China and Hong Kong', highlighted the significance for elite HEls of developing and maintaining international networks of connection, financed by donors from the global South (Benneworth and Hospers, 2007; Engel and del-Palacio, 2009; Petruzzelli et al., 2010). The knowledge generated from these networks - whose membership included university alumni - was intended to benefit populations of the global South, as well as the HEls, located predominantly in the North.

\section{(iii) Facilitating equality of access}

A further substantial element of philanthropic giving focused on promoting equality of access, as part of a wider mission to support, or inspire, future generations of students. This was demonstrated through provision of needs-based financial aid, which has had a long history in the US and, in an era of declining state support, has increasingly been sought by UK HEls as they endeavour to remain internationally competitive (Turner, 2009; UUK, 2009; Schuyt, 2010; Breeze et al., 2011). We found evidence of needs-based provision across a number of geographical scales. At the local community level, donations often supported place-based 'outreach' programmes, targeting young people based in specific geographical areas who would not usually have considered attending university. For example, Ohio State University announced a series of privately funded scholarships directed at members of the local community:

Granville philanthropists J. Gilbert and Louella H. Reese are calling the community to action with this $\$ 10$ million challenge. This challenge will raise endowed funds to support scholarships benefiting students attending Central Ohio Technical College and The Ohio 
State University at Newark in perpetuity. [...] J Gilbert Reese is often referred to as one of the founding fathers of Ohio State Newark and COTC. (The Ohio State University, News, 23 June 2010)

Similarly, Dartmouth College broadcast a donation to fund scholarships to benefit graduates from Chicago:

Diana and Bruce Rauner '78 have given \$1.3 million to endow a scholarship for Dartmouth undergraduates from the Chicago area. The annual scholarship will name three Rauner Scholars at Dartmouth, with preference for graduates of Chicago public schools and the Chicago metropolitan area who have acute financial need. (Dartmouth College, News, 28 October 2011)

Although the gifts were presented as supporting students in 'need', this type of provision was frequently combined with an HEl's imperative to continue to operate at an elite level by seeking out the best 'talent'. As such, the presentation of these donations by HEls raises questions about the underlying motivations of some universities in promoting equality of access (Noble et al., 2008). Moreover, the emphasis in the above examples on supporting a specific social group within a selected area, led to what Salamon has described as 'philanthropic particularism' (1987: 39). A by-product of non-profit and voluntary sector activity more generally, Salamon argued that it can result in uneven distribution of resources 'leav[ing] significant elements of the community without care' (1987: 41; see also: Havens and Schervish, 2005; Wolpert, 1988, 2003). Equally, it may contribute to the concentration of philanthropic support in the worldleading universities, and the neglect of newer or less well known institutions.

Such donations were reproduced across geographical scales, with HEls publicising needsbase donations which enabled enrolment of students nationally and globally. For example, the 
University of Oxford announced in 2012 a scholarship programme to support UK undergraduates:

The biggest philanthropic gift for undergraduate financial support in European history will underpin a major new scholarship programme at the University of Oxford - making it possible, starting this autumn, for students from low-income backgrounds to complete their studies with zero upfront study and living costs. [...] In addition, Moritz-Heyman scholars will receive financial support during vacations [...] (University of Oxford, News, 11 July 2012)

Similarly, in 2011, Duke University reported a donation to fund needs-based provision for both US and international students:

Duke University trustee Bruce Karsh and his wife Martha have donated $\$ 50$ million to Duke for a permanent endowment to support need-based financial aid for undergraduate students from the United States and other countries, President Richard $\mathrm{H}$. Brodhead announced Monday. This gift is the largest donation made by individuals to support financial aid in the university's history. The gift includes $\$ 30$ million for U.S. students and $\$ 20$ million for international students. (Duke University, News, 5 December 2011)

In the above depictions, HEls were defining themselves - in a role often assumed by government and / or private industry, and highlighted by Hennemann (2010) and Petruzzelli et al (2010) - as 'gatekeepers', using private donations to facilitate advancement and mobility via the recruitment and retention of selected individuals, within and across national borders (Ward, 2008; Sidhu, 2009). 
The two examples below describe substantial donations to universities from overseas philanthropists: respectively, a Russian émigré businessman, Leonard Blavatnik, and Indian alumnus and chair of the Tata Group, Ratan Tata. In both cases, the gifts were portrayed by the HEIs as enhancing their global appeal, by enabling access for international students:

In July 2010 Mr Leonard Blavatnik gave $£ 75$ million to establish the Blavatnik School of Government; a historic gift to create Europe's first school of government. This global outlook will reflect the strongly international character of Oxford's graduate community, two-thirds of whom are from overseas. (University of Oxford, Annual Review 2009-2010)

Hoping to spur innovation at Harvard and in the surrounding community while providing a spark for the economy, the Harvard Business School (HBS) announced plans Thursday (Oct. 14) for two building projects, one aimed at training new global leaders and the other at fostering entrepreneurship. [...] "Ratan Tata knows firsthand the transformative educational opportunities offered through Harvard Business School's executive education programs," said Harvard President Drew Faust. "Thanks to this generous gift, HBS will be able to expand its already robust offerings in executive education, deepening ties with leaders across the country and around the globe." (Harvard University, News, 14 October 2012)

In the above two texts, the donors were presented as enhancing the global appeal and connectedness of the already world-renowned universities through the provision of financial support based on student need and facilitating equality of access (Noble et al., 2008; Chiu and Sharfman, 2011). Moreover, the language used in these extracts has been 'socially determined' through the selection of adjectives (Fairclough, 2003: 22), with the Blavatnik gift being described as 'historic' and the school of government as 'Europe's first'. Superlatives such as 'largest', biggest', 'first of its kind', appeared frequently in $\mathrm{HEl}$ texts to represent the donations, 
suggesting that universities wished to project the gift, and the giver, as globally groundbreaking. In the second quotation, a direct link was made between the donor's personal experience of the $\mathrm{HEI}$ as a student and their subsequent success after graduation. HEls sought to produce these biographical narratives within their literature to motivate future generations of scholars and academics, and to encourage other 'transformational contributions' (Thompson et al., 2010). In a further example, businessman and Ohio State University donor, Leslie Wexner, recalled the debt he owed his alma mater:

"I have often said that but for The Ohio State University, I would not have had an opportunity to receive a college degree," Mr. Wexner said. "Attending this university changed my life, and I continue to witness the incredible potential this institution has to do the same thing for others." (The Ohio State University, News, 10 February 2012)

References to business success of the philanthropist in the official documentation, and the active investment in 'talent', ostensibly irrespective of financial means, served as expressions of institutional competitive reach (Demeritt, 2000; Henneman, 2010; Petruzelli et al., 2010). Through these messages, the university aimed to identify and utilise 'talent' in order to be at 'the forefront of science and technology' (Caltech, News, 29 January 2010), to 'advance [their] leadership position' (Northwestern University, News, 19 July 2011) and to fund various distinguished professorships intended to attract 'leading academic[s] who [have] demonstrated excellence and international recognition' (National University of Singapore, News, 12 June 2012). This desire to compete involved linking with preferred partners across disciplines and geographical scales (Benneworth and Hospers, 2007; Engel and del-Palacio, 2009; Henneman, 2010) and, equally, the ability to negotiate priorities with the donor. As we have seen, motivations behind making a particular gift were often linked explicitly by the HEls to experiences in the philanthropist's personal, family and business life. 


\section{Discussion and Conclusion}

Our analysis has indicated that elite HEls used representations of philanthropy to project a carefully crafted image as leaders in addressing contemporary global issues of social and cultural concern. In particular, universities perceived themselves to be preserving a notion of cultural heritage, as promoting cross-cultural interaction and as educational leaders, reaching out to the best 'talent'. Yet, universities, through their engagement with private philanthropists, communicated messages which extended beyond conventions of cultural heritage. In seeking to enhance cross-cultural dialogue, the HEls, in their official documentation, recognised the contribution of donors whose roots were often in countries of the global South. The reference to donor origin - reflecting individual personal mobilities (Merriman et al., 2008; Brooks and Waters, 2011; Cresswell, 2012) - gave legitimacy to the engagement by universities with issues of global concern, including poverty and public health. Equally, HEI provision of financial support, through philanthropic donations, for students from disadvantaged backgrounds not only demonstrated a recognition of, and subscription to, certain moral imperatives, it also permitted the university to generate a sense of loyalty among students who might become future, influential, alumni. Examination of texts published by our sample of leading HEls, therefore, uncovered diverse spatial encounters between the institution and the private philanthropist, with the cross-cultural reach of universities being consolidated and extended in the process. We draw attention to three ways in which our empirical research advances theoretical work on the transformative nature of HEIs as global centres of learning.

First, the linkages between private philanthropy and elite HEls were marked by strong powers of association. Donor practices were both socially situated and inherently geographical (Rabbitts, 2012), with the universities' official literature making reference to the philanthropist undertaking personal journeys, 'inspiring' future generations and engaging in debates on the world stage. These associations represented an important point of departure in advancing 
conceptions of philanthropy and mapping linkages with donor mobility and the internationalisation of higher education (Brooks and Waters, 2011; Findlay et al., 2012; Holloway and Jöns, 2012). Donors to these elite HEls came not just from the North, but from different parts of the globe. Powers of association therefore transcended national boundaries, and served to enhance the image of HEls as globally connected institutions. The transnational mobility of the philanthropists conferred on universities legitimacy, and credibility, when engaging in certain research activities related to specific overseas locations.

Second, philanthropic activity cut across the global North and South, with elite AngloAmerican universities, for example, receiving considerable financial support from donors with roots in China, India, the Middle East and Ukraine. This evidence builds on, but also departs from, the literature on HEIs as centres of calculation, seeking to know and control 'distant others' (Latour, 1987; Driver, 1992; Lambert and Lester, 2004; Jöns, 2009). Arguably, by contributing to knowledge produced by institutions located in the affluent regions, donors who were based - or had family origins - in the South reinforced the elitist position of leading Northern HEls and perpetuated geographical and social inequalities (Salamon, 1987; Noble et al, 2008; Hopkins, 2011). However, our analysis has indicated that influential networks of transnational alumni were also active in shaping the priorities and research agendas of these same institutions, facilitating initiatives which ostensibly benefited individuals located in the South, and permitted the circulation of new knowledge beyond networks of elite HEls. These practices of giving reflected the complex relations between university and philanthropist, with the HEls using private donations to define themselves as facilitators of improved mobility, personal advancement and equality of access (Ward, 2008; Sidhu, 2009). They were informed by the donor's genealogy, in particular, their homeland, previous sites of learning and places of work. 
Third, philanthropy was deployed to enhance the transformative power of HEIs. Drawing on earlier theorisations of the HEI as a site of innovation (Benneworth and Hospers, 2007; Engel and del-Palacio, 2009; Petruzzelli et al., 2010), we have demonstrated that large donations from philanthropists enabled universities to present themselves in their institutional documentation as world leaders in a highly competitive global economy. As such, elite HEls were involved in their own 'world-making' (Harvey et al., 2011: 425-426), using philanthropic gifts to enhance their institutional status and, arguably, exert greater influence on the world stage. Our findings emphasise that closer attention should be given to 'strategic philanthropy' (Saiia et al., 2003: 170ff; Ball, 2008; Osei-Kofi, 2010), not only from the perspective of the donor, but also from the $\mathrm{HEI}$. The public presentation of these donations no doubt required careful management, to satisfy both donor expectations and institutional goals. Whilst we were not party to negotiations between the HEls and their large-scale donors, our analysis of the institutional literature sheds light on the imperatives through which success in both securing the donation, and its subsequent presentation, depended. These included, for the HEIs, effective communication with a strong transnational alumni network coupled with strategic institutional leadership to ensure that the forms of presentation appealed to a range of external audiences. This paper has demonstrated that the personal spatial settings in which the encounters between donors and institutions take place are profoundly important in shaping both the socio-cultural positioning of the university and the public biography of the donor. 


\section{Acknowledgements}

We would like to thank the universities that responded to our queries. We are also grateful for the helpful suggestions received by the journal editor and the insightful feedback from all three referees.

\section{Caption}

Table 1: Sample 50 elite international universities (THE, 2011)

Table 2: The transformative role of HEls: identified themes

Table 3: Distribution of charitable causes by HEI

\section{Notes}

1. Clusters of Innovation are entrepreneurial networks characterised by greater mobility of resources (people, capital, and information), increased velocity of business development and a culture of personal mobility that lead to 'an affinity for collaboration and the development of durable relationships' (Engel and del-Palacio 2009).

2. Although the National University of Singapore traces its origins back to the early twentieth century, the first university - the University of Malaya - was established on site in 1949.

3. POSTECH was founded in 1986. 


\section{References}

Abbott, M. and Doucouliagos, C. (2003) The efficiency of Australian universities: a data envelopment analysis, Economics of Education Review 22, 1: 89-97.

Ackers, L. (2005) Moving people and knowledge: scientific mobility in the European Union. International Migration 43, 5: 99-131.

Adam, T. (2004) (ed) Philanthropy, Patronage and Civil Society: Experiences from Germany, Great Britain, and North America. Bloomington: Indiana University Press.

Adam, T. (2009) Buying Respectability: Philanthropy and Urban Society in Transnational Perspective, 1840s to1930s. Bloomington: Indiana University Press.

Altbach, P. and Knight, J. (2007) The internationalization of HE: motivations and realities, Journal of Studies in International Education 11, 3/4: 290-305.

Andersson, J., Sadgrove, J. and Valentine, G. (2012) Consuming campus: geographies of encounter at a British university, Social and Cultural Geography 13, 5: 501-515.

Ball, S. (2008) New Philanthropy, New Networks and New Governance in Education, Political Studies 56, 4: 747-765.

Ball, S., Davies, J., David, M. and Reay, D. (2002) 'Classification' and 'Judgement': social class and the 'cognitive structures' of choice of Higher Education, British Journal of Sociology of Education 23, 1: 51-72. 
Ball, S., Junemann, C. (2011) Education Policy and Philanthropy - The Changing Landscape of English Educational Governance, International Journal of Public Administration 34, 10: 646611.

Bell, M. (1998) Reshaping Boundaries: International Ethics and Environmental Consciousness in the Early Twentieth Century, Transactions of the Institute of British Geographers 23, 2: 151175.

Bell, M. (2000) American Philanthropy, the Carnegie Corporation and Poverty in South Africa, Journal of Southern African Studies 26, 3: 481-504.

Bell, M. (2002) Inquiring Minds and Postcolonial Devices: Examining Poverty at a Distance, Annals of the Association of American Geographers 92, 3: 507-523.

Bell, M., Butlin, R., and Heffernan, M. (1995) Geography and Imperialism, 1820-1940. Manchester: Manchester University Press.

Benneworth, P. and Hospers, G. (2007) The new economic geography of old industrial regions: universities as global-local pipelines, Environment and Planning C: Government and Policy 25, 6: $779-802$.

Blunt, A. (1994) Travel, Gender and Imperialism: Mary Kingsley and West Africa. New York: The Guilford Press.

Breeze, B. (2010) How Donors Choose Charities. London: University of Kent. 
Breeze, B., Gouwenberg, B., Schuyt, T. and Wilkinson, I. (2011) What role for public policy in promoting philanthropy? Public Management Review 13, 8: 1179-1195.

Brooks, R. and Waters, J. (2009) International higher education and the mobility of UK students, Journal of Research in International Education 8, 2: 191-209.

Card, D., Hallock, K. and Moretti, E. (2010) The geography of giving: The effect of corporate headquarters on local charities, Journal of Public Economics 94, 3-4: 222-234.

Cascione, G. (2003) Philanthropists in Higher Education: Institutional, Biographical, and Religious Motivations for Giving. New York: RoutledgeFalmer.

Chiu, S. and Sharfman, M. (2011) Legitimacy, Visibility, and the Antecedents of Corporate Social Performance: An Investigation of the Instrumental Perspective, Journal of Management, 37, 6: 1558-1585

Collins, J (2009) Creating women's work in the academy and beyond: Carnegie connections, 1923-1942 History Of Education 38, 6: 791-808.

Cresswell, T. (2012) Progress report. Mobilities II: Still, Progress in Human Geography, 36, 5: 645-653.

Demeritt, D. (2000) The New Social Contract for Science: Accountability, Relevance, and Value in US and UK Science and Research Policy, Antipode 32, 3: 308-329.

Dixon, D. (2010) Analyzing meaning in Gomez, B. and Jones III, J.P. (eds) Research Methods in Geography: A Critical Introduction. Chichester: Blackwell Publishing Ltd, pp. 392-407. 
Drayton, R. (2000) Nature's Government: Science, Imperial Britain, and the 'Improvement' of the World. New Haven: Yale University Press.

Drezner, N. (2011) Philanthropy and Fundraising in American Higher Education, Hoboken, NJ: Wiley Periodicals Inc.

Driver, F. (1992) Geography's empire: histories of geographical knowledge, Environment and Planning D: Society and Space 10: 23-40.

Driver, F. (2001) Geography Militant: Cultures of Exploration and Empire. Oxford: Blackwell.

Elliott, D. (2006) (ed) The Kindness of Strangers: Philanthropy and Higher Education. Lanham: Rowman and Littlefield.

Engel, J. and del-Palacio, I. (2009) Global networks of clusters of innovation: Accelerating the innovation process, Business Horizons 52, 5: 493-503.

Fairclough, N. (2003) Analysing Discourse: Textual Analysis for Social Research. London: Routledge.

Findlay, A., King, R., Smith, F., Geddes, A. and Skeldon, R. (2012) World class? An investigation of globalisation, difference and international student mobility, Transactions of the Institute of British Geographers 37, 1: 118-131.

Finnegan, D. (2008) The Spatial Turn: Geographical approaches in the history of science, Journal of the History of Biology 41, 2: 369-388. 
Forbes (2013) Profile: Curt Engelhorn, http://www.forbes.com/profile/curt-engelhorn/ (accessed 22/08/13)

Gidley, J., Hampson, G., Wheeler, L. and Bereded-Samuel, E. (2010) From Access to Success: An integrated approach to quality Higher Education informed by social inclusion theory and practice, Higher Education Policy 23, 1: 123-147.

Glassman, J. (2010) Critical Geography III: critical development geography, Progress in Human Geography 35, 5: 705-711.

Gluckler, J. and Ries, M. (2011) Why being there is not enough: organized proximity in placebased philanthropy, The Service Industries Journal 32, 4: 515-529.

Hall, S. (2008) Geographies of business education: MBA programmes, reflexive business schools and the cultural circuit of capital, Transactions of the Institute of British Geographers 33, 1: $27-41$

Harrison, M. (2005) Science and the British Empire, Isis 96, 1: 56-63.

Harvey, C., Maclean, M., Gordon, J. and Shaw, E. (2011) Andrew Carnegie and the foundations of contemporary entrepreneurial philanthropy, Business History 53, 3: 425-450.

Havens, J. and Schervish, P. (2005) Geography and generosity: Boston and beyond. Boston, MA: Center on Wealth and Philanthropy, Boston Foundation. 
Havens, J. and Schervish, P. (2007) Geography and giving: The culture of philanthropy in New England and the nation, Boston, MA: Center on Wealth and Philanthropy, Boston Foundation.

Heffernan, M. (1994) A state scholarship: the political geography of French international science during the nineteenth century, Transactions of the Institute of British Geographers 19, 1: 21-45.

Hennemann, S. (2010) Hierarchies in the science and technology system of China - System reforms and their consequences for knowledge flows, Geographische Zeitschrift 98, 3: 155174.

Holloway, S. and Jöns, H. (2012) Geographies of education and learning, Transactions of the Institute of British Geographers 37, 4: 482-488.

Hopkins, P. (2011) Multiple, marginalised, passé or politically engaged? Some reflections on the current place of social geographies, Social and Cultural Geography, 12:6, 533-538

Jayne, M., Valentine, G. and Holloway, S. (2010) Emotional, embodied and affective geographies of alcohol, drinking and drunkenness, Transactions of the Institute of British Geographers 35, 4: 540-554.

Jazeel, T. and McFarlane, C. (2007) Responsible learning: cultures of knowledge production and the north-south divide, Antipode 39, 5: 781-789.

Jazeel, T. and McFarlane, C. (2010) The limits of responsibility: a postcolonial politics of academic knowledge production, Transactions of the Institute of British Geographers 35, 1: 109-124. 
Jöns, H. (2008) Academic travel from Cambridge University and the formation of centres of knowledge, 1885-1954, Journal of Historical Geography 34: 338-362.

Jöns, H. (2009) 'Brain circulation' and transnational knowledge networks: studying long-term effects of academic mobility to Germany, 1954-2000, Global Networks 9, 3: 315-338.

Jöns, H. (2011) Transnational academic mobility and gender, Globalisation, Societies and Education 9, 2: 183-209.

Jöns, H., Livingstone, D. and Meusburger, P. (2011) in Meusburger, P., Livingstone, D. and Jöns, H. (eds) Geographies of Science. Springer: London, pp. ix-xvii.

Kelly, S. (2009) Private Money for the Public Good: Higher Education Philanthropy in Canada and the United States, Canadian Journal for New Scholars in Education 1, 2: 1-12.

Kohler, R. (1985) Science And Philanthropy - Wickliffe Rose And The International Education Board, Minerva 23, 1: 75-95.

Lambert, D. and Lester, A. (2004) Geographies of colonial philanthropy, Progress in Human Geography 28: 320-341.

Latour, B. (1987) Science in action: how to follow scientists and engineers through society. Cambridge, MA: Harvard University Press.

LeRoy, L. (1999) International grant making by U.S. foundations, Health Affairs 18, 3: 234-238. 
Leung, M (2011) Of corridors and chains: translocal developmental impacts of academic mobility between China and Germany, International Development Planning Review 33, 4: 475489.

Livingstone, D. (1994) Science and religion: foreword to the historical geography of an encounter, Journal of Historical Geography 20: 367-383.

Livingstone, D. (1995) Spaces of knowledge: Contributions towards a historical geography of science, Environment and Planning D: Society and Space 13: 5-34.

Livingstone, D. (2000) Putting Geography in its Place, Australian Geographical Studies 38: 1-9.

Lunn, J. (2009): The Role of Religion, Spirituality and Faith in Development: a critical theory approach, Third World Quarterly 30, 5: 937-951.

MacLeod, R. (1993) Passages in imperial science: from empire to commonwealth, Journal of World History 4, 1: 117-150.

Madge, C., Raghuram, P. and Noxolo, P. (2009) Engaged pedagogy and responsibility: A postcolonial analysis of international students, Geoforum 40, 1: 34-45.

McDonald, K. and Scaife, W. (2011) Print media portrayals of giving: exploring national 'cultures of philanthropy', International Journal of Nonprofit and Voluntary Sector Marketing 16, 4: 311324.

McFarlane, C. (2006) Transnational development networks: bringing development and postcolonial approaches into dialogue, The Geographical Journal 172, 1: 35-49. 
Merriman, P., Revill, G., Cresswell, T., Lorimer, H., Matless, D., Rose, G. and Wylie, J. (2008) Landscape, mobility, practice, Social and Cultural Geography, 9, 2: 191-212.

Moogan, Y., Baron, S. and Harris, K. (1999) Decision-making behaviour of potential higher education students, Higher Education Quarterly 53, 3, 211-228.

Naylor, S. (2005) Introduction: historical geographies of science - places, contexts, cartographies, British Journal for the History of Science 38, 1: 1-12.

Neuendorf, K. (2002) The Content Analysis Guidebook. London: Sage.

Noble, G., Cantrell, J., Kyriazis, E. and Algie, J. (2008), Motivations and forms of corporate giving behaviour: insights from Australia. International Journal Nonprofit Voluntary Sector Marketing, 13, 4: 315-325.

Noxolo, P. (2009) "My Paper, My Paper": Reflections on the embodied production of postcolonial geographical responsibility in academic writing, Geoforum 40,1: 55-65.

Odendahl, T. (1990) Charity begins at home: Generosity and self-interest among the philanthropic elite. New York: Basic Books.

Oldfield, S., Parnell, S. and Mabin, A. (2004) Engagement and reconstruction in critical research: negotiating urban practice, policy and theory in South Africa, Social and Cultural Geography 5 , 2: 285-299. 
Oleksiyenko, A. and Sá, C. (2010) Resource asymmetries and cumulative advantages: Canadian and US research universities and the field of global health, Higher Education 59, 3: 367-385.

Osei-Kofi, N. (2010) Coercion, possibility, or context? Questioning the role of private foundations in American higher education, Discourse: Studies in the Cultural Politics of Education, 31, 1: 17-28.

Ostrower, F. 1995. Why the Wealthy Give: The Culture of Elite Philanthropy. Princeton, NJ: Princeton University Press.

Owen, D. (1964) English Philanthropy, 1660-1960. Cambridge, MA: Belknap Press.

Palmer, S. (2010) Launching Global Health: The Caribbean Odyssey of the Rockefeller Foundation, Michigan: University of Michigan Press.

Parry, M., Field, K. and Supiano, B. (2013) The Gates Effect, The Chronicle of Higher Education. 14 July. http://chronicle.com/article/The-Gates-Effect/140323/ (accessed 22 August 2013).

Payton, R. and Moody, M. (2008) Understanding Philanthropy: Its meaning and mission. Bloomington, IN: Indiana University Press

Petruzzelli, A., Albino, V., Carbonara, N. and Rotolo, D. (2010) Leveraging learning behavior and network structure to improve knowledge gatekeepers' performance, Journal Of Knowledge Management 14, 5: 635-658. 
Pharoah, C. (2011) Private giving and philanthropy - their place in the Big Society, People, Place and Policy Online, 5, 2: 65-75.

Philo, C. and Pickstone, J. (2009) Unpromising configurations: Towards local historical geographies of psychiatry, Health and Place 15, 3: 649-656.

Powell, R. (2007) Geographies of science: histories, localities, practices, futures, Progress in Human Geography 31, 3: 309-329.

Rabbitts, F. (2012) Child sponsorship, ordinary ethics and the geographies of charity, Geoforum 43, 5: 926-936.

Sabri, D. (2011) What's wrong with 'the student experience'?, Discourse: Studies in the Cultural Politics of Education 32, 5: 657-667.

Saiia, D., Carroll, A. and Buchholtz, A. (2003) Philanthropy as Strategy: When corporate charity "Begins at Home", Business and Society, 42, 2: 169-201

Salamon, L. (1987) Of Market Failure, Voluntary Failure, and Third-Party Government: Toward a theory of Government-Nonprofit relations in the modern Welfare State, Nonprofit and Voluntary Sector Quarterly, 16, 1-2: 29-49.

Schervish, P. (1994) The moral biographies of the wealthy and the cultural scripture of wealth, in Schervish, P. (ed) Wealth in Western Thought: The Case for and Against Riches. Westport, CT: Praeger, pp167-208. 
Schervish, P. (1998). Philanthropy, in Wuthnow, R. (ed.) Encyclopedia of Politics and Religions. Washington, DC: Congressional Quarterly, pp600-603.

Schervish, P. (2005) Major donors, major motives: The people and purposes behind major gifts, New Directions for Philanthropic Fundraising 47: 59-87.

Schervish, P. (2006) The Moral Biography of Wealth: Philosophical reflections on the foundation of philanthrophy, Nonprofit and Voluntary Sector Quarterly 33, 3: 477-492.

Schuyt, T. (2010) Philanthropy in European welfare states: a challenging promise? International Review of Administrative Sciences 76, 4: 774-789.

Shapin, S. (1998) Placing the view from nowhere: historical and sociological problems in the location of science, Transactions of the Institute of British Geographers 23, 1: 5-12.

Sheppard, E. and Leitner, H. (2010) Quo vadis neoliberalism? The remaking of global capitalist governance after the Washington Consensus, Geoforum 41: 185-194.

Sidhu, R. (2009) The 'brand name' research university goes global, Higher Education 57: 2: 125-140.

Smith, S. (2010) UK Academies? Pride before the fall? Times Higher Education 16 September.

Thompson, J., Katz, S. and Briechle, P. (2010) A high level annual fund without the annual ask, International Journal of Educational Advancement 9, 4: 273-279. 
Thrift, N. (2002) Think and act like revolutionaries: episodes from the global triumph of management discourse, Critical Quarterly 44, 3: 19-26.

Times Higher Education (THE) (2011) World University Rankings 2011-2012

http://www.timeshighereducation.co.uk/world-university-rankings/2011-12/world-ranking (accessed 22 August 2013).

Turner, S. (2009) Common Across the Atlantic: The Underrepresentation of Low-Income Students in Higher Education in the US and the UK, in The Sutton Trust and Carnegie Corporation of New York (eds) Social Mobility and Education. London: The Sutton Trust.

Universität Heidelberg (2013) Heidelberg Centre for American Studies. Benefactors. http://www.hca.uni-heidelberg.de/ueberuns/benefactors.html (accessed 22/08/13)

Universities UK (UUK) (2009) Gifts That Grow: Charitable Giving in UK Higher Education. London: UUK.

Valentine, G. and Hughes, K. (2011) Shared space, distant lives? Understanding family and intimacy at home through the lens of internet gambling, Transactions of the Institute of British Geographers 37, 2: 242-255.

Ward, D. (2008) Globalization, Public Policies and Higher Education in Weber, L. and Duderstadt, J. (eds) The Globalization of Higher Education. Economica, University of California, pp 259-270. 
Waters, J. (2006). Geographies of cultural capital: education, international migration and family strategies between Hong Kong and Canada, Transactions of the Institute of British Geographers, 31, 2: 179-192.

Waters, J., Brooks, R. and Pimlott-Wilson, H. (2011) Youthful escapes? British students, overseas education and the pursuit of happiness, Social and Cultural Geography 12, 5: 455469.

Willetts, D. (2010) UK Universities global path in World Rankings, Times Higher Education 16 September.

Withers, C. and Mayhew, R. (2002), Rethinking 'disciplinary' history: geography in British universities, c. 1580-1887. Transactions of the Institute of British Geographers, 27, 1: 11-29.

Wolpert, J. (1988) The Geography of Generosity: Metropolitan Disparities in Donations and Support for Amenities, Annals of the Association of American Geographers, 78, 4: 665-679.

Wolpert, J. (2003) Voluntary Failure Theory and Nonprofit-Government Partnership, in Anheier, H. (ed) The Study of Nonprofit Enterprise: Theories and Approaches, New York: Kluwer Academic / Plenum Publishers, pp171-183. 


\begin{tabular}{|c|c|c|}
\hline University & $\begin{array}{l}\text { Country I } \\
\text { Region }\end{array}$ & $\begin{array}{l}\text { THE 2011- } \\
2012 \text { Rank }\end{array}$ \\
\hline California Institute of Technology (Caltech) & US & 1 \\
\hline Harvard University & US & 2 \\
\hline University of Oxford & UK & 4 \\
\hline University of Cambridge & UK & 6 \\
\hline Massachusetts Institute of Technology (MIT) & US & 7 \\
\hline University of Chicago & US & 9 \\
\hline Yale University & US & 11 \\
\hline University of California Los Angeles (UCLA) & US & 13 \\
\hline University College London & UK & 17 \\
\hline University of Toronto & Can & 19 \\
\hline Carnegie Mellon University & US & 21 \\
\hline Duke University & US & 22 \\
\hline University of Washington & US & 25 \\
\hline Northwestern University & US & 26 \\
\hline McGill University & Can & 28 \\
\hline University of Tokyo & Jap & 30 \\
\hline University of Illinois at Urbana Champaign & US & 31 \\
\hline University of California San Diego & US & 33 \\
\hline University of Hong Kong & $\mathrm{HK}$ & 34 \\
\hline The University of Edinburgh & UK & 36 \\
\hline University of Melbourne & Aus & 37 \\
\hline University of California Davis & US & 38 \\
\hline National University of Singapore (NUS) & Sing & 40 \\
\hline New York University & US & 44 \\
\hline Ludwig-Maximilians-Universität München & Gny & 45 \\
\hline London School of Economics and Political Science (LSE) & UK & 47 \\
\hline Brown University & US & 49 \\
\hline Peking University & China & 49 \\
\hline Pohang University of Science and Technology (POSTECH) & Rep Korea & 53 \\
\hline The Ohio State University & US & 57 \\
\hline University of Pittsburgh & US & 59 \\
\hline École Normale Supérieure & $\mathrm{Fr}$ & 59 \\
\hline University of Zürich & Switz & 61 \\
\hline École Polytechnique & $\mathrm{Fr}$ & 63 \\
\hline McMaster University & Can & 65 \\
\hline University of Bristol & UK & 66 \\
\hline Utrecht University & Neth & 68 \\
\hline Rice University & US & 72 \\
\hline Universität Heidelberg & Gny & 73 \\
\hline University of Queensland & Aus & 74 \\
\hline Emory University & US & 75 \\
\hline Tufts University & US & 77 \\
\hline Lund University & Swe & 80 \\
\hline University of Rochester & US & 81 \\
\hline Uppsala University & Swe & 87 \\
\hline Dartmouth College & US & 90 \\
\hline University of Amsterdam & Neth & 92 \\
\hline Case Western Reserve University & US & 93 \\
\hline Michigan State University & US & 96 \\
\hline Purdue University & US & 98 \\
\hline
\end{tabular}

Table 1: Sample 50 elite international universities (THE, 2011) 


\begin{tabular}{|r|l|r|}
\hline & Theme & $\begin{array}{l}\text { Metaphorical } \\
\text { Form(s)* }\end{array}$ \\
\hline 1 & Custodians of heritage & $\mathrm{A}$ \\
\hline 2 & Facilitators of cultural exchange & $\mathrm{A}$ \\
\hline 3 & Promotors of knowledge exchange & $\mathrm{A}, \mathrm{B}$ \\
\hline 4 & Global interconnectedness & $\mathrm{A}, \mathrm{B}$ \\
\hline 5 & Dedicated spaces of learning & $\mathrm{A}, \mathrm{B}, \mathrm{C}$ \\
\hline 6 & State of the art facilities & $\mathrm{A}, \mathrm{B}$ \\
\hline 7 & Recognised expertise in education and research & $\mathrm{A}, \mathrm{B}$ \\
\hline 8 & Leaders in public affairs & $\mathrm{B}$ \\
\hline 9 & Respondents to global emergencies & $\mathrm{B}$ \\
\hline 10 & Facilitators of partnership working & $\mathrm{A}, \mathrm{B}$ \\
\hline 11 & Global centres of teaching and learning & $\mathrm{B}$ \\
\hline 12 & Research into significant topics & $\mathrm{B}$ \\
\hline 13 & Developers of academic and student 'talent' & $\mathrm{B}, \mathrm{C}$ \\
\hline 14 & Competitors on the world stage & $\mathrm{A}, \mathrm{B}$ \\
\hline 15 & Enablers of social mobility & $\mathrm{C}$ \\
\hline 16 & Initiators of opportunity across generations & $\mathrm{C}$ \\
\hline 17 & Support of / engagement with local community & $\mathrm{A}, \mathrm{C}$ \\
\hline 18 & Transnational alumni networks & $\mathrm{A}, \mathrm{B}, \mathrm{C}$ \\
\hline
\end{tabular}

\section{*Metaphorical forms}
A Centre of heritage and source cultural dialogue
B Respondents to global concerns
C Facilitators of equality of access

Table 2: The transformative role of HEls: identified themes

Note: These themes were identified through a content analysis of over $250 \mathrm{HEI}$ publications, and then categorised into three metaphorical forms assumed by the selected HEls when describing their encounters with individual donors. 


\begin{tabular}{|c|c|c|c|}
\hline Universities & Country & $\begin{array}{l}\text { Geographical } \\
\text { Region }\end{array}$ & Sample Charitable Causes \\
\hline $\begin{array}{l}\text { California Institute of } \\
\text { Technology (Cal) } \\
\text { Harvard University (Hvd) } \\
\text { Massachusetts Institute of } \\
\text { Technology (MIT) } \\
\text { University of Chicago (UoC) } \\
\text { Yale University (Ya) } \\
\text { University of California Los } \\
\text { Angeles (UCLA) } \\
\text { Carnegie Mellon University } \\
\text { (CMU) } \\
\text { Duke University (Du) } \\
\text { University of Washington (UoW) } \\
\text { Northwestern University (NW) } \\
\text { University of Illinois at Urbana } \\
\text { Champaign (UIUC) } \\
\text { University of California San } \\
\text { Diego (UCSD) } \\
\text { University of California Davis } \\
\text { (UCD) } \\
\text { New York University (NYU) } \\
\text { Brown University (Br) } \\
\text { Ohio State University (OSU) } \\
\text { University of Pittsburgh (UoP) } \\
\text { Rice University (Ri) } \\
\text { Emory University (Em) } \\
\text { Tufts University (Tu) } \\
\text { University of Rochester (UoR) } \\
\text { Dartmouth College (Da) } \\
\text { Case Western Reserve } \\
\text { University (CWRU) } \\
\text { Michigan State University } \\
\text { (MSU) } \\
\text { Purdue University (Pu) } \\
\text { University of Toronto (UoT) } \\
\text { McGill University (McG) } \\
\text { McMaster University (McM) } \\
\text { Mory }\end{array}$ & $\begin{array}{l}\text { US } \\
\text { US } \\
\text { US } \\
\text { US } \\
\text { US } \\
\text { US } \\
\text { US } \\
\text { US } \\
\text { US } \\
\text { US } \\
\text { US } \\
\text { US } \\
\text { US } \\
\text { US } \\
\text { US } \\
\text { US } \\
\text { US } \\
\text { US } \\
\text { US } \\
\text { US } \\
\text { US } \\
\text { US } \\
\text { US } \\
\text { US } \\
\text { US } \\
\text { Can } \\
\text { Can } \\
\text { Can }\end{array}$ & North America & $\begin{array}{l}\text { University infrastructure (Da, MIT, Duke, Wash, Brn, } \\
\text { Ri, McG) } \\
\text { Collaboration with other HEIs (Cal) } \\
\text { Research: } \\
\text { Arts and humanities (Hvd, UoC, UCSD, OSU) } \\
\text { Sciences (UoC, UIUC, MSU, McG) } \\
\text { Engineering (UCSD, Pu) } \\
\text { Government, policy, economics (UCLA, Du, Br, UoR) } \\
\text { Business / enterprise (UCD, NYU) } \\
\text { Social sciences (UCSD) } \\
\text { Public health (UCLA, UIUC, UCSD) } \\
\text { Medical (NW, UCSD, OSU, UoP, Em, Tu, UoR, McG, } \\
\text { McM) } \\
\text { Veterinary medicine (UCD) } \\
\text { Global poverty (Da) } \\
\text { Global leadership (Hvd, UCLA) } \\
\text { Demographic change overseas (McM) } \\
\text { Preservation of cultural heritage (Ya) } \\
\text { Food security (McG) } \\
\text { Sustainable development (Du) } \\
\text { Education - primary and secondary (Du) } \\
\text { Overseas countries / cultures (UCLA, UoT, NYU, } \\
\text { CMU, Br, Em, Tu, CWRU, MSU) } \\
\text { Needs-based provision - local (OSU) } \\
\text { Needs-based provision - specific area (Du, Da) } \\
\text { Needs-based provision - national and international } \\
\text { (Du) }\end{array}$ \\
\hline $\begin{array}{l}\text { University of Oxford (Ox) } \\
\text { University of Cambridge (Cam) } \\
\text { University College London } \\
\text { (UCL) } \\
\text { University of Edinburgh (Ed) } \\
\text { London School of Economics } \\
\text { and Political Science (LSE) } \\
\text { University of Bristol (Bri) } \\
\text { Ludwig-Maximilians-Universität } \\
\text { München (LMUM) } \\
\text { Universität Heidelberg (Hbg) } \\
\text { École Normale Supérieure } \\
\text { (ENS) } \\
\text { École Polytechnique (EP) } \\
\text { Utrecht University (UU) } \\
\text { University of Amsterdam (Am) }\end{array}$ & $\begin{array}{l}\text { UK } \\
\text { UK } \\
\text { UK } \\
\text { UK } \\
\text { UK } \\
\text { UK } \\
\text { Gny } \\
\text { Gny } \\
\text { Fr } \\
\text { Fr } \\
\text { Neth } \\
\text { Neth }\end{array}$ & Europe & $\begin{array}{l}\text { University infrastructure (Ox, Cam, Hbg, Lu, Up) } \\
\text { Research: } \\
\text { Sciences (Ox, EP) } \\
\text { Government, policy, economics (Ox, LSE) } \\
\text { Business / enterprise (Lu) } \\
\text { Public health (Ox) } \\
\text { Medical (Ed, Br, Up) } \\
\text { Global health (Ox) } \\
\text { Global leadership (LSE) } \\
\text { Sustainable development (Cam) } \\
\text { Biodiversity (Ox) }\end{array}$ \\
\hline
\end{tabular}




\begin{tabular}{|c|c|c|c|}
\hline $\begin{array}{l}\text { Lund University (Lu) } \\
\text { Uppsala University (Up) } \\
\text { University of Zürich (Zu) }\end{array}$ & $\begin{array}{l}\text { Swe } \\
\text { Swe } \\
\text { Switz }\end{array}$ & & $\begin{array}{l}\text { Infectious diseases - overseas (Ox) } \\
\text { Overseas countries / cultures (Ox, Cam, Ed, LSE, } \\
\text { Hbg) } \\
\text { Needs-based provision - national and international } \\
\text { (Ox, Cam, UCL) }\end{array}$ \\
\hline $\begin{array}{l}\text { University of Tokyo (To) } \\
\text { University of Hong Kong (HK) } \\
\text { National University of Singapore } \\
\text { (NUS) } \\
\text { Peking University (PKU) } \\
\text { Pohang University of Science } \\
\text { and Technology (POSTECH) }\end{array}$ & $\begin{array}{l}\text { Jap } \\
\text { HK } \\
\text { Sing } \\
\text { China } \\
\text { Rep } \\
\text { Korea }\end{array}$ & Asia & $\begin{array}{l}\text { University infrastructure (PKU, HK, NUS) } \\
\text { Research: } \\
\text { Arts and humanities (HK) } \\
\text { International studies (PKU) } \\
\text { Public health (NUS) } \\
\text { Medical (HK, NUS) } \\
\text { Mathematics / Statistics (HK) } \\
\text { Government, policy, economics (HK) } \\
\text { Business / enterprise (NUS) } \\
\text { Overseas countries / cultures (PKU) } \\
\text { Attract academic 'talent' (NUS) }\end{array}$ \\
\hline $\begin{array}{l}\text { University of Melbourne (Mel) } \\
\text { University of Queensland } \\
\text { Australia (Qld) }\end{array}$ & $\begin{array}{l}\text { Aus } \\
\text { Aus }\end{array}$ & Australasia & $\begin{array}{l}\text { Research: } \\
\text { Sciences (Mel) } \\
\text { Engineering (Mel, Qld) } \\
\text { Medical (Mel, Qld) } \\
\text { Veterinary medicine (Mel) } \\
\text { Overseas countries / cultures (Mel) } \\
\text { Needs-based provision - national and international } \\
\text { (Mel, Qld) }\end{array}$ \\
\hline
\end{tabular}

Table 3: Distribution of charitable causes by HEI

Note: The inclusion of charitable causes in this Table is indicative, with selection based on causes supported by major, individual donations. The headings describing the causes are generic and overlaps exist, for example, between 'public health' and 'medicine'. 'University infrastructure' includes gifts to fund the construction of buildings, laboratories and libraries. Donations to the academic disciplines listed under 'Research' include financial support for chairs and visiting scholars. 